\title{
Entre la doble vara y el privilegio. La administración de la justicia frente al fenómeno de la sodomía masculina en el Virreinato del Perú (Siglos XVI-XVII)
}

por

Fernanda Molina

CONICET/UBA

Este artículo indaga en la actuación de la justicia tanto civil como episcopal en asuntos relativos al delito de sodomía en el Virreinato del Perú entre los siglos XVI y XVII. Particularmente, analiza en qué medida los orígenes familiares, sociales y étnicos de los acusados así como su pertenencia a redes o grupos de poder pudieron influir en la actuación de los magistrados y en la fulminación de las causas. Asimismo, en el marco de los procesos seguidos por sodomía, examina cómo los fueros y la lógica corporativa también pudieron constituir mecanismos eficaces a fin de manipular y eludir las disposiciones judiciales.

Palabras claves: sodomía; justicia; fueros; Virreinato del Perú.

\section{INTRODUCCIÓN}

Para la sociedad colonial peruana la sodomía constituyó una de las transgresiones más execrables de su época en la medida en que, al tratarse de un pecado pero también de un delito, no sólo atentaba contra el orden natural creado por Dios sino también contra el orden social que procedía de esa obra divina. En el plano legislativo - cuyo ordenamiento derivaba de las leyes peninsulares-, su gravedad quedó de manifiesto a través de una serie de dispo-

${ }^{1}$ Una versión preliminar fue presentada en XVI Congreso Internacional de AHILA, "El nacimiento de la libertad en la Península Ibérica y Latinoamérica. Orígenes, Evolución y Debates", Universidad de Cádiz, San Fernando de Cádiz, España, 6 al 9 de Septiembre de 2011. 
siciones que no sólo establecieron como forma de condenación la muerte en la hoguera -penalidad máxima solo aplicable a los delitos de herejía y de lesa majestad- sino también la confiscación y la pérdida de bienes, el uso de la tortura, las facilidades tanto acusatorias como probatorias y, lo más importante, la posibilidad de acusar, procesar y castigar a todos los individuos que fueran sospechado del crimen con total prescindencia de su status o condición social $^{2}$.

Incluso, la gravedad que comportaba la sodomía confinaba a los nobles culpados a la pérdida de su status con la concomitante aplicación de castigos físicos y tormentos de los que la nobleza se encontraba exenta. Sin embargo, más allá de la letra, esa aspiración universalista encontraba serios límites en una sociedad que hacia de la desigualdad un modo de ordenamiento. En muchas oportunidades, los magistrados que intervinieron en las causas procedieron contra los inculpados en virtud de la calidad y el estado que estos ostentaban, poniendo de manifiesto los prejuicios sociales y étnicos de los que se nutría su práctica judicial pero también la administración de justicia en su conjunto. La intervención y la manipulación que ciertas personas encumbradas o facciones políticas hicieron sobre el correcto seguimiento de las causas también favorecieron el ejercicio parcial de la justicia que, de este modo, expresaba el intrincado vínculo entre su administración y los grupos de poder. Pero si bien estas conductas tendientes a favorecer o proteger a ciertos individuos constituían mecanismos exógenos al sistema judicial, también existieron dispositivos legales - como la apelación a los fueros o la lógica corporativa- que persiguieron objetivos semejantes aunque en el marco del sistema judicial.

En ese escenario, este trabajo se propone indagar en el tratamiento que los tribunales civiles, eclesiásticos e inquisitoriales peruanos hicieron del fenómeno de la sodomía masculina, a fin de dilucidar en qué contextos la eximición judicial de algunos inculpados respondió a la apelación de mecanismos judiciales formales y en qué contextos fue el resultado de una «mala justicia». A través del estudio de una serie de procesos criminales incoados por sodomía, esta investigación sugiere que el éxito de algunos sodomitas para eludir o morigerar las penas correspondientes residió tanto en las jerarquías sociales

2 La pragmática emitida por los Reyes Católicos el 22 de agosto de 1497 establecía que: «qualquier persona de qualquier estado, condición, preeminencia, o dignidad que sean, que cometiere el delito nefando contra naturam (...) que sea quemado en las llamas del fuego, en el lugar, i por la justicia a quien pertenesciere el conoscimiento, i punición del tal delito». Carlos IV, 1805: 428. 
y étnicas originadas en la estructura social colonial peruana como en una cultura jurídica que hacía de la desigualdad jurídica un derecho.

\section{JERARQUíAS FLUIDAS}

Si bien la sociedad colonial peruana de los siglos XVI y XVII puede considerarse una sociedad de Antiguo Régimen, en la medida en que estaba conformada por estamentos definidos por el lugar de nacimiento, también constituyó un espacio de fluidez social hasta entonces sin precedentes. No obstante, los hombres y mujeres virreinales utilizaron el lenguaje del «nacimiento» y de la «sangre» para definir y clasificar a los diferentes grupos e individuos que formaban parte de la sociedad colonial y para describir fenómenos que más tarde serían denominados como clase y raza ${ }^{3}$. Toda esta serie de definiciones procedían de los estamentos privilegiados de la sociedad castellana, especialmente, de la nobleza que, aun cuando no tomó parte de manera directa de la conquista y la colonización, logró exportar sus valores a los nuevos territorios. Conquistadores, hidalgos sin fortuna, pequeños propietarios rurales, pastores y agricultores que participaron de las empresas ultramarinas, compartieron la ideología señorial de la clase nobiliaria, sustentada en la explotación de la tierra y de los hombres, la cual procuraron hacer realidad en el nuevo contexto ${ }^{4}$. Muchos de los jefes que lideraron las guerras de conquista, a pesar de proceder de los estratos más bajos de la sociedad peninsular, lograron obtener, a través de una exitosa performance en los campos de batalla, una serie de privilegios entre los que se contaban mercedes de tierras, encomiendas y hasta títulos de nobleza. Esta «maleabilidad» social, especialmente, experimentada durante los primeros años que siguieron al «descubrimiento», trastocó la estratificación social peninsular y permitió que individuos de status dudoso o simples pecheros precedieran en al cadena de mando a muchos hidalgos en el proceso de conquista y colonización ${ }^{5}$.

El éxito de los conquistadores y de los primeros colonos dependió, en gran medida, de la obtención de una encomienda. El acceso casi irrestricto a la explotación de la mano de obra indígena durante los primeros tiempos permitió una temprana y considerable acumulación. Además, aun cuando los encomenderos nunca lograron transformar sus encomiendas en feudos, la ausencia de reglas y de control oficiales posibilitó la apropiación y el usufructo,

\footnotetext{
3 Schwartz y Salomon, 1999, vol. 2: 444.

4 Presta, 2000, vol. 2: 57.

5 Ibidem: 58.
} 
en los hechos, de las tierras y de los recursos de sus encomendados. No obstante, en la medida en que los derechos de encomienda se concedían por dos vidas, la del titular y la de su legítimo sucesor, la institución tenía sus días contados. Esta situación contribuyó, por un lado, a la diversificación de las actividades económicas de los encomenderos, por ejemplo, a través de la explotación minera y, por otro lado, a la connivencia con altos funcionarios virreinales y con figuras influyentes de la política metropolitana, a fin de obtener beneficios en sus nuevos negocios y de asegurarse la continuidad como grupo dirigente ${ }^{6}$. Las alianzas matrimoniales fueron la vía principal para estrechar las relaciones entre estos grupos que configuraron lo que podría denominarse una elite de nuevo cuño, basada en el status de «nobleza indiana» de los encomenderos y sus descendientes, en las riquezas de los comerciantes y empresarios exitosos y en la corrupción de los funcionarios virreinales. De este modo, se ponía de manifiesto, una vez más, tanto la ductilidad de los sectores dominantes de la sociedad colonial para adaptarse a diferentes contextos como la maleabilidad del sistema de estratificación indiano ${ }^{7}$.

Sin embargo, a medida que se consolidaba el orden colonial, la movilidad «vertical» tendió a disminuir, fosilizándose las posiciones de aquellos individuos ahora devenidos en grupo dominante. Cuando las migraciones se hicieron más intensas y el hecho de proceder de la península no era suficiente para acceder a las posiciones privilegiadas como en los primeros tiempos, comenzó a crecer un grupo de individuos que aunque de origen peninsular o criollo formaban parte de los sectores subalternos de la sociedad colonial. Al interior de este grupo se encontraban individuos de los más diversos rangos y oficios: comerciantes al menudeo, pequeños propietarios rurales, pulperos, fleteros, dueños de tambos o pasadas, capataces, carpinteros, herreros, viñateros, «maestros» constructores, mineros, escribanos, mayordomos administradores, etc $^{8}$. En el caso de aquellos individuos que no contaban con oficio ni conexiones, la alternativa consistía en ponerse al servicio de miembros de los sectores acomodados como criados o pajes. Los más, sueltos y buscavidas, a veces nombrados «soldados», abrigaban la esperanza de participar de alguna guerra de conquista en donde recrear las condiciones de los primeros tiempos. La «pacificación» de los territorios fronterizos constituyó, en estos casos, una

6 Elliot, 1990: 26.

7 Las presiones fiscales que impulsaron a Felipe IV a autorizar a los virreyes indianos la venta de títulos de hidalguía constituyen otro ejemplo de la volatilidad del sistema de estratificación social colonial. Elliot, 1990: 25.

8 Presta, 2000, vol. 2: 68 . 
opción relativamente exitosa a lo largo del siglo XVII ${ }^{9}$. Los curas doctrineros también formaron parte de este segmento de la sociedad peninsular. A diferencia de los obispos, canónigos e inquisidores que formaban parte activa de las órdenes religiosas y los grupos de poder, la cotidianidad de los curas que tenían a su cargo la evangelización de los indígenas no distaba demasiado de la de los seglares más empobrecidos de la sociedad colonial.

Pero más allá de las diferencias socioeconómicas que distanció a los peninsulares o a los criollos entre sí, el hecho de proceder de la península o de descender de sus pobladores los exentaba del pago de tributo, el cual constituía una atribución exclusiva de las poblaciones indígenas sometidas. Por lo tanto, a diferencia de Castilla y de otras partes de España donde las diferencias estamentales redundaron en la distinción entre pecheros y nobles, en la sociedad colonial indiana, la fuerza de la «sangre» benefició al conjunto de la población hispánica y fundó una sociedad racialmente segregacionista.

Fuera de las denominadas «noblezas indígenas» que gozaron de los mismos privilegios que el estamento peninsular dominante, fundamentalmente, en lo relativo a la eximición de impuesto, la base material sobre la que se asentó toda la organización colonial reposó sobre las poblaciones conquistadas que, progresivamente, fueron transformándose en una masa campesina indiferenciada. Como se mencionara, la encomienda fue la institución principal a través de la cual se organizó el trabajo indígena y si bien aspiraba a ser un mecanismo medido y organizado de explotación, la inicial ausencia de controles efectivos la transformó en un sistema cuasi servil. Los límites que la corona trató de poner a las demandas irrestrictas de los encomenderos -y las luchas sangrientas que de allí se derivaron- fueron motivados, no tanto por una preocupación regia por el bienestar de sus vasallos en las Indias, como por la competencia por el excedente ${ }^{10}$. El sistema de reducciones también debe interpretarse como otro mecanismo orientado a maximizar la explotación del trabajo indígena. Aun cuando la congregación residencial en los llamados «pueblos de indios» -físicamente separados de la «república de españoles»decía perseguir fines educativos y edificantes para los nativos, lo cierto es que las reducciones fueron motivadas por intereses fiscales, en la medida en que facilitaba el cobro del tributo y favorecía la recomposición demográfica de la principal fuente de recaudación impositiva. Durante el gobierno del Virrey Francisco de Toledo también se suprimieron las exenciones tributarias a los nobles indígenas, con excepción de los curacas, sus primogénitos y de los

\footnotetext{
9 Molina, 2006: 48-51.

10 Sobre los conflictos entre encomenderos y la corona castellana ver Lohmannn Villena, 1977 y Bataillon, 1995 (1062): 79-96
} 
grupos inferiores en la escala social indígena que, como los yanaconas, habían estado reservados del pago del tributo ${ }^{11}$. Esto provocó un proceso de homogenización al interior de las sociedades conquistadas al tiempo que amplió la base tributaria de la corona ${ }^{12}$. Otra de las medidas que contribuyeron a la recomposición de la Real Hacienda fue la Visita General que Toledo organizó entre los años 1570 y 1575 . Su principal objetivo era delinear un mapa demográfico completo y más realista, a partir del cual establecer una tasa impositiva que se ajustara a las capacidades de las menguadas comunidades indígenas y organizar un sistema rotativo de trabajo forzado -la mita-, para la explotación de los yacimientos mineros ${ }^{13}$.

De los intentos reales por proteger y aislar a los indígenas de la influencia de la población peninsular, sólo había sobrevivido el espíritu segregacionista y discriminatorio. El sistema de reducciones había favorecido las presiones de los particulares sobre una población que había sido compelida a abandonar su antiguo patrón de asentamiento disperso para circunscribirse territorialmente. Por otro lado, la coacción para incorporar a los indios al sistema de trabajo y a la economía monetaria europea también había militado en contra de las aspiraciones oficiales por mantener separada la «república de indios» de la «república de españoles» ${ }^{14}$. Además, muchos indígenas se desplazaron a las ciudades donde se asentaron en las denominadas parroquias de indios, las cuales conservaban un trazado y una lógica similar a las reducciones y se ubicaban en la periferia del asentamiento central ocupado por los peninsulares $^{15}$. Los intentos de las autoridades virreinales por distanciar a ambas sociedades o por conservar la pureza «racial» representaban, a esta altura de los acontecimientos, una quimera.

No obstante, la segregación étnica no siempre había sido parte de la política oficial. En los primero años, la corona no sólo se había mostrado tolerante respecto del cruzamiento entre peninsulares y mujeres indígenas sino que, incluso, las había fomentado ${ }^{16}$. La primera generación de mestizos -especialmente las mujeres- nacidos de esas uniones fue incorporada al linaje paterno, a pesar de su ilegitimidad, alcanzando casi las mismas prerrogativas que los peninsulares recién arribados al territorio americano ${ }^{17}$. No obstante, su multi-

\footnotetext{
11 Bonnett Vélez, 1999.

12 Elliot, 1990: 22. Palomeque, 2000: 111.

13 Bonnett Vélez, 1999: 107-108.

14 Elliot, 1998 (1987): 24.

15 Poloni Simard, 2000: 117.

16 Mörner, 1969 (1967): 46.

17 Presta, 2004: 41-62
} 
plicación descontrolada convirtió a los mestizos en una incomodidad a la hora de encasillarlos en los límites jurídicos impuestos por «las dos repúblicas». Cuando el crecimiento de la población mestiza se reveló irreversible, las autoridades coloniales comenzaron a ver con recelo a quienes pronto identificaron como un evidente riesgo fiscal y social. A diferencia de los primeros mestizos, la segunda generación fue percibida como nociva y peligrosa para el orden social. En cierta medida, el recelo que los mestizos despertaban en las autoridades coloniales estaba vinculado con su dudosa lealtad a la sociedad peninsular ya que, después de todo, seguían mamando de sus madres las «malas inclinaciones». De este modo, los mestizos fueron descriptos como viciosos, pendencieros, mentirosos, ociosos e inconstantes ${ }^{18}$. Sin embargo, muchos de los mestizos de la segunda generación lograron asimilarse al mundo paterno, especialmente, cuando su progenitor no contaba con descendencia legítima a la cual legar sus heredades. Si bien este tipo de «movilidad étnica» daba cuenta del carácter negociable y fluido de las identidades raciales, también es cierto que se restringió a aquellos que descendían de personas destacadas dentro de la sociedad colonial. Por el contrario, la pléyade de mestizos no reconocida por sus padres, descendiente de peninsulares humildes o producto de relaciones ocasionales, pululaba por la colonia entremezclada con los sectores más bajos de la sociedad peninsular o entre los indígenas. Pero más allá de las diversas procedencias, trayectorias y destinos finales, los mestizos, en tanto categoría jurídica, racial y cultural, no lograron trascender su representación negativa en el seno de la sociedad colonial. Un ejemplo de esto, fue la prohibición de portar armas u ordenarse religiosamente, incluso, para los mestizos pertenecientes al estamento dominante ${ }^{19}$.

Pero no sólo el mestizaje entre peninsulares y mujeres nativas provocó situaciones contradictorias. La población de origen africano que arribó a las Indias también participó de las complejas relaciones interétnicas, contribuyendo a la complejización del mapa racial y multiplicando las categorías fenotípicas conocidas como «castas». Aun cuando la mayoría eran esclavos, gozaban de mayor status que los indígenas, en la medida en que habían llegado como sirvientes de los conquistadores y, como tales, formaban parte del universo español ${ }^{20}$. No obstante, eso no significó que pudieran emanciparse de los estereotipos que durante siglos habían elaborado las sociedades europeas, según las cuales, los africanos eran amantes del libertinaje, estaban inclinados a la rebeldía, eran promotores de alborotos y motines y se aficionaban a los

\footnotetext{
18 Ares Queija, 2000a: 121-144.

19 Ibidem, 2000b: 83-84.

20 Ibidem: 76.
} 
desórdenes sexuales ${ }^{21}$. Incluso, aquellos africanos libres que estaban asimilados culturalmente a los valores europeos aún cargaban con los estigmas de sus antepasados como si esos atributos pudieran transmitirse por la sangre. Pero más allá de la existencia de africanos libres o libertos, la masa crítica de la población negra continuaba sometida a la esclavitud. Según las Partidas alfonsí, los esclavos eran considerados seres humanos y no bienes muebles lo que redundó, entre otras cosas, en la capacidad para intervenir en las instancias judiciales, ya sea pleiteando para obtener la libertad, acusando a sus amos por malos tratamientos o abusos sexuales, querellando por asuntos menores y hasta compareciendo como testigos. Esta conceptualización en torno a los esclavos generó permanentes tensiones al interior de una legislación que si bien les negaba jurídicamente la libertad, también los cobijaba, permitiéndoles litigar por sus derechos. Por otro lado, aun cuando la imagen dominante de la esclavitud en América ha estado vinculada con la economía de plantaciones o con las explotaciones auríferas, en el Virreinato del Perú, la esclavitud fue, ante todo, un fenómeno urbano ${ }^{22}$. En las ciudades coloniales, los negros esclavos se dedicaban, fundamentalmente, a los servicios domésticos, en función de su asimilación a la cultural hispana, y representaban un símbolo de prestigio y poder de una familia ${ }^{23}$. Siguiendo el modelo de organización patriarcal, los esclavos se integraban a la familia de sus amos, incluso, estableciendo relaciones afectivas con ellos. Con todo, la situación de los esclavos domésticos era más restrictiva y controlada que la de aquellos individuos alquilados por un jornal que debían «compartir» con sus amos. En el caso de los esclavos libres u horros, su condición de emancipados no los eximía de los prejuicios asociados con su origen ${ }^{24}$. Al igual que en el caso de los mestizos, las autoridades se mostraron preocupadas por individuos que por su condición jurídica gozaban de la libertad de circular por tabernas, pulperías, rancherías y eran reacios a establecerse de manera duradera con nuevos $\operatorname{amos}^{25}$. Estos individuos se establecieron en barrios periféricos en donde convivían con mulatos, indios y mestizos, lo que contribuyó a acelerar el proceso de miscegenación iniciado tempranamente.

21 Borja, 1996: 189.

22 Según Bowser de los 3.000 esclavos que, se estima, habitaban la jurisdicción virreinal peruana, aproximadamente la mitad estaba concentrada en la ciudad de Lima. Bowser, 1977 (1974): 32.

23 Bernand, 2002: 38.

${ }^{24}$ Los llamados «negros horros», esclavos a quienes se les había concedido la libertad o la habían comprado ellos mismos. Olsen, 2002: 65.

25 Bernand, 2002: 34. 
Por lo tanto, si bien la sociedad virreinal peruana fue una sociedad estamental, en la que la «sangre», el origen familiar y el status determinaban la posición social de los individuos, también es cierto que lo fue en un sentido sui generis. Raza, etnicidad, procedencia familiar, situación socioeconómica y background cultural fueron algunas de las variables que se conjugaron para definir la posición de los individuos en la sociedad colonial. En un escenario relativamente flexible, individual o colectivamente, algunos hombres y mujeres virreinales tuvieron la posibilidad de explotar, según los contextos, las ventajas que cada una de esas variables ofrecía, aunque siempre bajo ciertas condiciones bien precisas y determinadas. Fue en ese en donde se insertaron las experiencias sodomíticas que por incluir, además, una dimensión subjetiva e íntima configuraron y reconfiguraron las relaciones sociales, raciales y culturales.

\section{LA DOBLE VARA}

La mayoría de los procesos criminales seguidos por sodomía revelan una actuación parcial de los magistrados en virtud de la «calidad» del acusado. Vamos a encontrar una justicia menos «benévola» y «complaciente»-especialmente en el fuero secular- a medida en que el indiciado como sodomita se aleja social y étnicamente del grupo dominante. Esto afectó, particularmente, a negros, mulatos y mestizos así como a individuos de origen peninsular provenientes de los estamentos más bajos de la sociedad colonial. Por el contrario, peninsulares acomodados y figuras relevantes de la vida política colonial gozaron de mayores ventajas si no para expiar completamente sus culpas, por lo menos, para hacer menos deshonrosa su condenación. Veamos algunos ejemplos.

En 1578, el Doctor Barros de San Millán, por entonces oidor de la Real Audiencia de La Plata, debió enfrentar un primer juicio por sodomía iniciado por su colega y rival Juan de Matienzo. La acusación se fundamentaba en los dichos del alcalde mayor de minas de Potosí, Juan de Bengoechea, quien había acusado al Doctor Barros por «los defectos en el cumplimiento de su empleo» ${ }^{26}$. Es importante remarcar que la denuncia «por sodomía» se insertaba en una acusación más amplia que sindicaba al Doctor Barros como enemigo y opositor de la política que el virrey Toledo llevada adelante en lo

26 Juan de Bengoechea, alcalde mayor de las minas de Potosí, con Manuel Barros de San Millán, oidor de la Audiencia de La Plata, sobre defectos en el cumplimiento de su empleo, 1579, Archivo General de Indias, Sevilla (AGI), Escribanía, 844A. 
tocante a los derechos de los llamados señores naturales ${ }^{27}$. Sin embargo, en medio de las informaciones del caso, falleció su principal impulsor, el oidor Juan de Matienzo, de manera que los jueces de la causa, conocedores del enfrentamiento que traían ambos oidores, decidieron remitir el «negocio» al mismísimo virrey. Toledo, en una carta dirigida al rey en abril de 1580, manifestaba que «no e querido hasta agora proueer nada hasta que vuestra magestad lo mande determinar» ${ }^{28}$. Sorpresivamente, el parecer del rey, a través del Consejo de Indias, era muy diferente al que sostenían los agentes coloniales en Charcas. No sólo desestimaba la acusación por sodomía sino que hacia 1585 lo promovía a Presidente de la Audiencia de Quito. Con esta decisión, anclada en el consejo, el rey pretendía mitigar socialmente los estigmas de la acusación y ofrecerle al Doctor Barros un nuevo contexto donde desempeñar sus funciones libre de las sospechas del delito. Sin embargo, en 1590 y ya como flamante presidente de la Audiencia de Quito, el Doctor Barros debió trasladarse a la Real Audiencia de Lima para enfrentar un segundo proceso por sodomía. En esta oportunidad, no sólo se lo sindicaba de haber tenido acceso carnal con Andrés Cupín y Pedro, dos antiguos esclavos, sino también de haber favorecido varias causas seguidas por pecado nefando en el tiempo en que se desempeñaba como oidor en La Plata. No se sabe qué tipo de protección gozaba en la Real Audiencia de Lima, como otrora en el Consejo de Indias, pero lo cierto es que esos contactos le permitieron escapar, por segunda vez, del fuego redentor. Cupín, por su parte, fue hallado culpable de haber cometido el delito de sodomía con otros negros en la cárcel de la ciudad de Los Reyes. Tras largas sesiones de tortura, finalmente, murió relajado por el brazo secular, no sin antes retractarse de la acusación que había lanzado contra su antiguo amo.

Otro caso afamado fue el protagonizado por un canónigo de La Plata, el Doctor Gaspar González de Sosa quien, al igual que el Doctor Barros, tuvo que enfrentar en dos oportunidades la nefanda acusación ${ }^{29}$. Si bien a lo largo de ambos procesos el canónigo fue hallado culpable -los testimonios, indicios y pruebas eran por demás elocuentes- en 1595, la justicia eclesiástica sólo aplicó una pena ordinaria, «recomendándole» que cuidara su comportamiento en virtud del estado que ostentaba. Por el contrario, sus principales «cómplices», el boticario Juan González y el barchilón Alonso López del Valle, fueron

27 Murra, 2002: 435.

28 Levillier, 1924: 247.

29 Cartas y expedientes del Cabildo Eclesiástico de Charcas, 28 de febrero de 1613, AGI, Charcas, 140. Traslado de dos causas criminales incoadas el 12 de agosto de 1595 y el 11 de marzo de 1608, respectivamente, contra el Dr. Gaspar Gonzáles de Sosa por sodomía. 
remitidos a la justicia civil que los condenó a la pena capital en la forma legalmente establecida. Pero a pesar de las amonestaciones realizadas por el Cabildo Eclesiástico, en 1608, el canónigo debió comparecer nuevamente ante la justicia eclesiástica, en esta oportunidad, acusado de mantener una relación ilícita con Diego Mejía, su criado. La «amistad» entre los inculpados causó tal revuelo en la jurisdicción que los capellanes de la iglesia de La Plata le habían solicitado en reiteradas ocasiones que despidiera a Mejía de su servicio. A diferencia de lo acontecido durante el primer proceso, los jueces del Cabildo se mostraron menos condescendientes y, «por averlo cometido con continuación», lo condenaron al perdimiento de sus beneficios y prebendas, la confiscación de todos sus bienes y la degradación hasta dejarlo en rango de lego para remitirlo a la justicia seglar ${ }^{30}$. Si bien parecía el final del periplo sodomita del Doctor González, los miembros del Cabildo no contaban con el último recurso a disposición del canónigo: la apelación a la justicia arzobispal metropolitana con sede en la ciudad de Los Reyes. A pesar de los alegatos que opusieron sus pares del Cabildo Eclesiástico -como que no «seria justo ni dezente que V.M. permita que un cavildo tan principal y honrado tenga por su colega y compañero un hombre tan infamado»- finalmente, en 1612, el arzobispo limense revocó la sentencia dictada en primera instancia y «mandó que le sean devueltos y restituidos los bienes (...) y su prebenda y su canonicato» ${ }^{31}$. Además, en virtud de la «infamia» con la que se había querido manchar su persona, el rey emitió una cédula en donde se encargaba el traslado del canónigo a otra iglesia del obispado para que estuviera libre del estigma del proceso. La suerte de su criado fue menos promisoria. Procesado por la justicia civil y sin capacidad de apelación, Mejía fue condenado a destierro por diez años, seis de ellos en galera y sin sueldo, so pena de muerte. Asimismo, se le prohibió usar el oficio real que generosamente le había obsequiado su amo y se procedió a vender el cargo de regidor que ostentaba, además de secuestrarle todos sus bienes.

No obstante, la doble vara de la justicia no sólo operó en aquellos casos que involucraban a figuras encumbradas de la vida virreinal. El proceso seguido contra Cristóbal Zamorano en 1620 por haber tenido tocamientos deshonestos, próximos al pecado nefando, con Juan Moreno, su criado, también revela cómo los estereotipos y los prejuicios étnicos estaban a la orden del

30 Ibidem, folios 26v- 27, f/p. Traslado de la causa criminal incoada el 11 de marzo de 1608 contra el Dr. Gaspar Gonzáles de Sosa por sodomía.

31 Ibidem, folios $3 \mathrm{v}$ y $28 \mathrm{v}$, f/p. Traslado de dos causas criminales incoadas el 12 de agosto de 1595 y el 11 de marzo de 1608, respectivamente, contra el Dr. Gaspar Gonzáles de Sosa por sodomía. 
día a la hora de impartir justicia. Gracias al testimonio de una serie de testigos, así como al careo entre los implicados, los jueces de la causa determinaron la existencia de actos propincuos a la sodomía. Aun cuando ambos fueron hallados culpables, Juan Moreno recibió la pena de 200 azotes públicos y cuatro años en las galeras, los cuales debía cumplir so pena de muerte mientras que a su amo le impusieron vergüenzas públicas, la pena pecuniaria de cuatro mil ducados y seis años de destierro. No satisfecho con el fallo, Zamorano apeló en situación de revista, consiguiendo la revocación de la vergüenza pública ${ }^{32}$. Si bien debió cumplir con la pena del destierro, logró sortear el reconocimiento público de su delito $\mathrm{y}$, de este modo, guardar parte de su honra mancillada. Juan Moreno no tuvo ninguna posibilidad de apelación y debió cumplir con una de las penas más cruentas luego de la relajación: las galeras, además de la degradación que representaban los castigos corporales. Pero la inequidad de la justicia no sólo se había revelado en su fallo. A lo largo del proceso, los jueces recurrieron a la aplicación de tormentos físicos sobre Juan Moreno a fin de obtener una confesión. Este uso selectivo de prácticas procesales ponía de manifiesto una serie de creencias muy extendidas en el período, según las cuales, la tortura constituía el único medio eficaz para doblegar a «embusteros pertinaces», como los negros, los mulatos o los indios.

Si bien casos citados pueden constituir un escenario propicio para el ejercicio sesgado de la justicia -en la medida en que involucraban a individuos socialmente desiguales cuando no vinculados por relaciones de dominación y dependencia- no obstante, la administración de justicia también dejaba notar sus prejuicios raciales y étnicos en aquellas causas en las que los implicados eran individuos de baja laya. El juicio por sodomía iniciado el 2 de septiembre de 1603 contra el mulato Jerónimo Ponce y el esclavo morisco Domingo López, presos en las cárceles de la Casa de la Contratación, da cuenta de ello. A diferencia de las causas anteriores, cuyas averiguaciones podían demorarse entre uno y hasta diez años antes de emitir la sentencia final, en este caso, la justicia fue sumamente expeditiva. El 30 de septiembre de 1603, es decir, a 28 días de iniciada la causa, los jueces intervinientes dictaminaron que ambos acusados

sean sacados en forma de justicia acostumbradas y con bos de pregoneros que manifiesten sus delitos e sean traydos por las calles publicas y acostumbradas de esta ciudad (...) y en el sitio y parte de esta ciudad acostumbrado sean puestos dos

32 El fiscal con Cristóbal Zamorano y Juan Moreno, su criado, residentes en Panamá, sobre pecado nefando, 18 de mayo de 1621, AGI, Escribanía, 451A, fol. 230v. 
palos en los quales sean arrimados y se les de garrote hasta que naturalmente mueran y después sus cuerpos sean quemados en llamas de fuego hasta que se conbiertan en polbo y zeniça para que perezca su memoria ${ }^{33}$.

Sin dudas, la celeridad de la sentencia se fundaba en una serie de estereotipos en torno a la sexualidad de negros y musulmanes, a quienes se los asociaba con los vicios de la carne. Además, como híbridos raciales, en su calidad de mulato y morisco, representaban individuos inclinados a desafiar el orden natural.

A pesar de que los datos son fragmentarios, un acercamiento de tipo cuantitativo al problema confirma la tendencia hacia la aplicación selectiva de las condenas, en función de la pertenencia étnica y social. Entre los sodomitas virreinales que fueron hallados culpables de cometer el pecado nefando, los de origen hispano constituían una abrumadora mayoría respecto de los negros, mulatos, mestizos y moriscos ${ }^{34}$. Sin embargo, la severidad de las penas fueron mayores para aquellos individuos procedentes de los estamentos más bajos de la sociedad virreinal. De los 45 españoles hallados culpables, sólo 6 recibieron como castigo la pena capital, 3 fueron enviados a galeras y el resto recibió penas menores como el destierro, la vergüenza pública o la abjuración de levi en aquellos casos competentes al Santo Oficio. Por su parte, de los 10 individuos pertenecientes a los otros grupos étnicos, la mitad tuvieron como destino el fuego expiatorio, dos fueron enviados a galera y el resto fue desterrado, azotado o recibieron una combinación de penas. Los españoles que recibieron como castigo tanto la hoguera como las galeras -que también representaba una de las penalidades más graves- pertenecían a los segmentos más bajos de la sociedad peninsular como marineros, grumetes, enfermeros o boticarios. Asimismo, cabe destacar que aun cuando los procesos revelan una participación y responsabilidad activa en la causa incoada, algunos peninsulares fueron absueltos de culpa y cargo. En esos casos, se trató de personalidades destacadas de la vida política o eclesiástica local como fueron los casos del Doctor Barros de San Millán y el Doctor Gaspar González de Sosa, entre otros.

33 El fiscal con Jerónimo Ponce y Domingo López, mulatos, residentes en Sevilla, sobre haber cometido el pecado nefando, 30 de septiembre de 1603, AGI, Escribanía 1075C, fol. $98 \mathrm{v}$.

${ }^{34} \mathrm{La}$ población indígena estuvo ausente dentro de esta categoría. Los indígenas que aparecen en los procesos judiciales, sin excepción, suelen participar de la relación sodomítica en función de su dependencia social respecto de otro individuo, por lo general, de origen hispano. 
DERECHO AL PRIVILEGIO

Sin dudas, los preconceptos sociales y étnicos con los cuales los magistrados guiaban su práctica judicial tendieron a favorecer a aquellos peninsulares pertenecientes a los estamentos privilegiados de la sociedad colonial. Estos elementos, sin embargo, deberían considerarse constitutivos de la propia administración de justicia y no simples atributos de algunos funcionarios particulares. Después de todo, una legislación que se basaba en la existencia de dos repúblicas separadas, que consideraba a los indígenas como menores de edad o que eximía a la población de origen peninsular del pago del tributo por el sólo hecho de haber nacido en la península, constituyen muestras claras de una justicia atenta al género, al status y al origen social y étnico de los procesados.

No obstante, se trataban de mecanismos que operaban de manera informal en el ejercicio cotidiano de la justicia y que, por esa misma informalidad, podía tener resultados diversos. En esos contextos, algunos individuos contaron con mecanismos adicionales, legalmente establecidos, que hacían de la justicia el privilegio de unos pocos. De particular importancia fue la existencia de fueros especiales que, entre otros, gozaron las personas eclesiásticas, miembros de las órdenes religiosas y algunos funcionarios del Santo Oficio. Este privilegio se derivaba de la concepción organicista de la sociedad que tenía su correlato en el plano jurídico: las cabezas de esas instituciones -pero también las de las asociaciones profesionales, los municipios, las ciudades, los señoríos, etc.- ejercían el poder político como jurisdicción, es decir, como capacidad para establecer normas y administrar justicia en el ámbito de sus competencias $^{35}$. El principio corporativista permitía que el origen inmediato de la jurisdicción procediera de la corporación -en detrimento de los ordenamientos más universales- y que la capacidad de ejercer poder jurisdiccional también residiera en ella. Eso era posible, además, por el hecho de que la cultura jurídica del período fue el resultado de tradiciones heterogéneas, cuya su conformación no implicó la supresión de los ordenamientos anteriores sino su intricada convivencia aun cuando se basaran en la misma orientación de principios. El resultado de ese proceso fue la existencia de un orden pluralista que se tradujo en un entreverado jurisdiccional, en la medida en que todos los ordenamientos jurídicos - de orígenes distintos y diferentes grados de alcance y amplitud- operaban sobre territorios y comunidades coincidentes ${ }^{36}$.

35 Garriga, 2004: 19.

36 Vallejo y Petit, 1992, vol. 3: 721-760. Hespanha, 2002: 104. 
En ese escenario, la apelación a los fueros representó para algunos sodomitas una estrategia de defensa.

El caso protagonizado por el Doctor Gaspar González de Sosa puede brindarnos algunas pistas al respecto. Ya hemos visto cómo el canónigo, a diferencia de sus compañeros de aventura, logró salir indemne en dos oportunidades de la acusación de sodomía. Eso se debió no sólo a la gravedad de su persona y al estado que investía sino, y fundamentalmente, a la posibilidad de ampararse en el fuero eclesiástico. Si bien, como se mencionara, las causas criminales seguidas contra las personas eclesiásticas podían juzgarse al interior del propio fuero, el tratamiento de ciertos delitos -como el crimen nefando contra natura- excedían las competencias de la justicia episcopal. En esos casos, se recomendaba degradar a los clérigos hasta dejarlos en estado de lego, entregarlos a la justicia secular que, a partir de allí, continuaría con el desarrollo de la causa. Sin embargo, esto no aconteció en el caso del Doctor González quien, en ambas oportunidades, fue juzgado por el Cabildo Eclesiástico. A decir verdad, la apelación a los fueros siempre había sido una materia de debate, especialmente, en temas de mixti fori que solían enfrentar a la justicia secular, de un lado y a la eclesiástica, del otro. A lo largo del proceso seguido contra el Doctor González pueden vislumbrarse retazos de esas luchas jurisdiccionales que llegan a nosotros a través de un nutrido intercambio epistolar entre el Cabildo Eclesiástico de La Plata y el Consejo de Indias. En una de las misivas, el vicario de la catedral, preocupado por «restaurar» el honor de los eclesiásticos solicitó al Rey limitar la actuación de la Audiencia en el caso del canónigo, por tratarse de un asunto tocante a la justicia episcopal. Respondiendo satisfactoriamente a sus reclamos, en otra carta, el Rey ordenaba:

mando que se borren del pliego donde caen las dichas palabras sacandolas a la letra donde estan y como estan escriptas [en la Audiencia] para que se den y entreguen al dicho vicario para que proceda en la causa contra los culpados ${ }^{37}$.

Sabemos que, de todos modos, los jueces eclesiásticos hallaron culpable al Doctor González del delito de sodomía; pero también sabemos que, finalmente y tras haber apelado a la justicia episcopal metropolitana, el canónigo fue dado por libre de culpa y cargo gracias a la disposición última emitida por del arzobispo limense. Sin embargo, aun cuando los miembros del Cabil-

37 Cartas y espedientes del Cabildo Eclesiástico de Charcas, 28 de febrero de 1634, AGI, Charcas, $140,5 \mathrm{v}, \mathrm{f} / \mathrm{p}$. Traslado de una causa criminal incoada el 12 de agosto de 1595 contra el Dr. Gaspar Gonzáles de Sosa por sodomía. 
do Eclesiástico de La Plata y el arzobispo de la ciudad de Los Reyes tuvieran pareceres encontrados respecto a la culpabilidad del canónigo, ambos actuaron motivados por la necesidad de preservar la honorabilidad de la institución que dirigían y por mantener en secreto las transgresiones cometidas por sus miembros: en un caso, sustrayendo la causa de la justicia civil y, en el otro, borrando, mediante la absolución, cualquier mácula contra el inculpado. Sugerentemente, ni la causa incoada en la jurisdicción de La Plata ni la apelación remitida a la justicia arzobispal se encuentran hoy en los repositorios correspondientes, lo que puede sugerirnos la existencia de prácticas basadas en el ocultamiento cuando no en la «desaparición» definitiva del caso.

En 1634, cuando el affaire González comenzaba a quedar en el olvido, el obispado de La Plata fue testigo de una nueva causa, en esta oportunidad, iniciada contra el arcediano Pedro de Arandia por haber intentado cometer el delito de sodomía con Antón, su esclavo. En la causa seguida contra el arcediano, según el Cabildo Eclesiástico, «por difamacion publica que corria en esa ciudad con mucha nota de que el canonigo don Pedro de Arandia tenía mala amistad con un negro su esclavo», la justicia civil pretendió intervenir a fin de encarcelar a los sospechosos pues entendía que se trataba de un delito tocante a su jurisdicción ${ }^{38}$. Sin embargo, tuvo que contentarse con el apresamiento del negro, ya que Arandia, gracias al fuero eclesiástico, logró eludir la cárcel pública. La intromisión de la justicia secular en un asunto que consideraban propio, provocó un profundo recelo entre los miembros del Cabildo Eclesiástico quienes no sólo se declaraban adictos a la causa de Arandia sino que incitaban a que «algunos predicadores moços y de poca experiencia ayan dicho en los pulpitos que se les hace injusticia a los reos» ${ }^{39}$. Esto generó un gran escándalo en la ciudad de La Plata, ya que a través de sus clérigos la Iglesia hacía público su rechazo a la intromisión de la Real Audiencia en un asunto que juzgaban propio. Pero el Cabildo Eclesiástico no se conformó sólo con vituperar durante las homilías a los oidores reales sino que el mismo arzobispo, frente al deshonor sufrido por la persona de Arandia, fue el encargado de peticionar al rey de «desterrarle [la causa] de la memoria de los hombres y que con no verlo en el cuerpo del cabildo se borre lo que ay de incontinencia ${ }^{40}$. El pedido del arzobispo se sustentaba en el procedimiento que se había seguido previamente con el Doctor Gaspar González de

38 Cartas y expedientes de Presidentes y Oidores de la Audiencia de Charcas, 8 de enero de 1633, Archivo General de Indias, Sevilla (AGI), Charcas 20, R12, N 121, fol.1.

39 Ibidem, fol. $1 \mathrm{v}$.

40 Cartas y expedientes del Cabildo Eclesiástico de Charcas, 1 de marzo de 18 de febrero de 1634, AGI, Charcas, 140, s/f. 
Sosa, por lo que la causa del canónigo no sólo había sentado un precedente sino que volvía a actualizarse mas de treinta años después. Por esas paradojas de la historia, Pedro de Arandia había sucedido al Doctor González en el cargo de asesor jurídico del cabildo de La Plata, revelándose como su fiel seguidor no sólo en las tareas pastorales.

Las órdenes religiosas también constituyeron ámbitos judicialmente protegidos, en la medida en tanto las autoridades episcopales como civiles tenían serias restricciones para intervenir en sus asuntos internos aun cuando se encontrara dentro de su diócesis o jurisdicción. Esa situación contribuyó a mantener bajo un halo de silencio aquellas conductas alejadas de la regla -especialmente las de índole sexual- que pudieran representar una mácula al conjunto de la orden. En ese escenario, los casos de sodomía intramuros salían a la luz cuando tomaban estado público, cuando uno de sus miembros podía utilizar la acusación para perjudicar a otro o cuando intervenía una institución externa como la Inquisición o la justicia real ${ }^{41}$. El proceso seguido contra el provincial Fray Domingo de Valderrama por cometer el pecado nefando con el novicio Juan de Silva en el convento de Nuestra Señora del Rosario de Lima es un claro ejemplo del primer caso. En un comienzo, las autoridades dominicas prefirieron mantener en secreto las irregularidades cometidas por el su provincial. Incluso, ante el pedido explícito del novicio para abandonar el hábito, en virtud de la incómoda situación a la Valderrama lo sometía en calidad de superior, decidieron denegarle la salida de la orden por temor a que denunciara la situación que se vivía en el convento. El temor no era infundado: la orden había estado en el ojo de la tormenta cuando otro de sus miembros, preso también por el pecado nefando, exigía que se sancionara «a Fray Domingo de Valderrama que es un puto y si uviera justicia para todos tambien castigaran al dicho Fray Domingo de Valderrama como le castigavan a el» ${ }^{42}$. Este ejercicio parcial de la justicia no sólo reproducía la estructura jerárquica de la organización monacal sino que alentaba la función del convento como un refugio seguro de los sodomitas. De hecho, las autoridades dominicas tomaron cartas en el asunto sólo cuando el provincial, viéndose cercado por la notoriedad y la publicidad de sus actos, decidió apostatar y huir del convento. Los principios de organización corporativa que tuvieron su correlato en el plano judicial $\mathrm{y}$, particularmente, la instauración de fueros especiales operaron, en muchos casos, como un refugio seguro para los sodomitas que pudieron gozar de ese privilegio.

41 Molina, 2013: 1-17.

42 Proceso contra Fray Domingo de Valderrama, 12 de febrero de 1596, Archivo Histórico Nacional, Madrid (AHN), Colección-Diversos, 45, $\mathrm{n}^{\mathrm{o}}$. 2, fol. 2v. 
No obstante, a pesar de toda esta serie de disposiciones para precisar el alcance de los fueros, parece que en la práctica no surtieron los efectos esperados, prolongando los conflictos jurisdiccionales entre los diferentes tribunales. De este modo, la existencia tanto de fueros eclesiásticos como inquisitoriales pudo haber contribuido a la preservación, en un sentido particular e inmediato, de la integridad de sus miembros, mientras que, en un sentido más general, pudo representar una estrategia para defender la honorabilidad de la institución como tal. En este sentido puede interpretarse la baja actuación de los tribunales eclesiásticos en los asuntos de sodomía, especialmente, cuando involucraba a sus propios miembros ${ }^{43}$.

\section{LA MALA JUSTICIA}

Pero aun cuando la administración de justicia era entendida en términos de privilegios y estaba sujeta a la persona del juez, los hombres y mujeres virreinales también percibieron la existencia de una «mala justicia», justamente, allí donde el privilegio y la actuación ecuánime del magistrado encontraban su límite. En estos casos, el uso de las influencias políticas, las presiones o la connivencia con los magistrados e, incluso, la intromisión directa sobre el desarrollo de las causas, también constituyeron mecanismos eficaces que permitieron a algunos sodomitas burlar a la justicia.

Esta serie de estrategias constituyó una prerrogativa que sólo estuvieron al alcance de aquellos individuos pertenecientes grupos o facciones con cierta ascendencia dentro de la política local o virreinal. Como se mencionara, debido al carácter infamante del delito, muchos de los procesos fueron manipulados, destruidos o ni siquiera llegaron a instancias judiciales. El proceso seguido por la Real Audiencia de La Plata en 1613 contra Diego Díaz de Talavera y Luis de Herrera, su criado, revela indicios al respecto. Según Juan de Villegas, el denunciante, dos años antes de iniciarse el proceso civil, él mismo en persona había presentado una petición ante juez eclesiástico en donde denunciaba a Diego Díaz de Talavera y a su criado por cometer el pecado nefando. Si bien en un comienzo el juez eclesiástico excomulgó a los acusados -reconociendo la existencia del delito-, más tarde, los absolvió gracias a la intermediación de algunos vecinos influyentes y del ruego de los propios excomulgados. No obstante, lo más significativo del caso fue que la petición nunca siguió su curso sino que, como manifestaba Villegas, «entien-

43 Sobre las luchas jurisdiccionales y las lógicas corporativas que influenciaron en la formación y fulminación de procesos por sodomía ver Molina: 2008: 141-186. 
de este testigo que borraron todo lo sustancial de la dicha petición o lo quitaron de la causa, no sabe cual de las dos cosas» por lo que dos años después el caso continuaba impune ${ }^{44}$. Asimismo, según el traslado, era tan pública y notoria la relación entre amo y criado que quienes abandonaban el Valle de Pitantora, donde moraban, «murmuran de cómo las justicias disimulan semejantes delitos poniendoles culpa de remision $»^{45}$.

Pero esta práctica no fue privativa de la justicia episcopal. En 1636, en la ciudad de Arequipa, el promotor fiscal inició una causa contra el pulpero Lorenzo Miguel y el adolescente José de Retamozo por haberlos sorprendido desnudos teniendo acceso carnal por el vaso trasero. El proceso desencadenó en una serie de vituperios públicos, amenazas físicas, heridas y hasta muertes, luego de que el juez de la Real Audiencia de Lima condenara a ambos, en ausencia, a la relajación por el brazo secular. El origen de esos excesos respondía al hecho de que José de Retamozo era «un muchacho hijo de xente muy válida», por lo que, rápidamente, su clan procuró, por todos los medios, alterar el resultado del fallo judicial ${ }^{46}$. En ese contexto, el primo del acusado, Don Fernando de Cárdenas, avisado de que se fulminaría la causa y que esto traería aparejado la afrenta a su linaje, no dudó en proferir palabras injuriosas contra quienes habían incoado la causa e incluso amenazarlos de muerte, lo que redundó en que el alcalde no sólo dejara en suspenso la aplicación de la pena capital sino que los diera por libre ${ }^{47}$.

No contento con eso, el «clan Retamozo» redobló su apuesta y, a fin de borrar cualquier mácula sobre su linaje,

quito de la causa las confesiones de los reos y el auto en que aceto ser acesor de ella el licenciado Matheo Ruiz de Sosa (...) y asimismo le quito la causa a Luis Ortiz de Uriarte escribano que avia comenzado a escribir en ella y conoserlo (...) quito de ellas las dichas confesiones a los reos y les admitio sus cargos sin averles

44 Proceso criminal seguido contra Diego Dias de Talavera y Luis de Herrera su criado por sodomía, 20 de julio de 1613, Archivo y Biblioteca Nacionales de Bolivia, Sucre (ABNB), Expedientes Coloniales, EC.1603.14, fol.12.

45 Ibidem, fol. $2 \mathrm{v}$.

46 Expediente incompleto de los autos seguido por el promotor fiscal D. Francisco de Castro contra D. Fernando de Cárdenas Zapatas por las amenazas de muerte y palabras injuriosas proferidas contra el alcalde de Arequipa D. Antonio de Aguilar y San Pedro y el escribano D. Juan Ortiz Uriarte por haber incoado causa contra el pulpero Lorenzo Miguel y el niño de once años José de Retamozo, primo del encausado Cárdenas, al haberlos sorprendido desnudos cometiendo el pecado nefando, 24 de marzo de 1636, Archivo General de la Nación de Perú, Lima (AGN), Real Audiencia, Causas Criminales, C1. leg. 1, fol. 1011v.

47 Ibidem, fol. 1121. 
hecho las devidas preguntas que resultavan de las información sumaria y se hizo la causa entre compadres en menor precio de la Real Justicia ${ }^{48}$.

Pero así como grupos de poder podían incidir sobre la actuación de los magistrados, en otros casos, fueron los encargados de administrar justicia quienes, de manera espontánea y sin mediar violencia, tendieron a proteger a algunos sodomitas sospechados. Las luchas jurisdiccionales constituyen un buen escenario para visualizar cómo algunos jueces pusieron al servicio de particulares su función de administradores. Esto puede observarse durante la elección del Comisario Inquisidor del obispado de Popayán. Si bien la Inquisición accedió a aceptar al candidato propuesto por el obispo, fue implacable con la autoridad episcopal en aquellos asuntos que consideraba de su competencia. En esa tarea, Gonzalo de Torres, el flamante comisario en funciones, no dudó en exigirle a su antiguo protector una serie de juicios que estaban en manos del tribunal eclesiástico pero que eran atribuciones del Santo Oficio. Por su parte, el obispo alegó la pérdida accidental de los procesos, aun cuando era "público y notorio» que el prelado había los había escondido «porque tocan a sus amigos, hermanos y hombres que an procurado se quemen los procesos y se entiende que algunos se a hecho ${ }^{49}$. Pero no sólo las autoridades eclesiásticas ponían frenos al ejercicio de la justicia de otros tribunales. En la diócesis de Nueva Granada, por entonces sufragánea de Lima, los jueces inquisidores solicitaron al obispo de esa jurisdicción una serie de causas formadas por la justicia eclesiástica que involucraban a funcionarios reales y que consideraban tocantes a la Inquisición. La reacción inmediata de la Audiencia consistió en un hostigamiento al obispo para que no revelara las causas al Santo Oficio. Según los inquisidores, la acuciante preocupación de los oidores estribaba, entre otras cosas, en el hecho de que algunos funcionarios aparecían indiciados como sodomitas, hipótesis que más tarde se comprobaría cuando a algunos de ellos les «cortaron la cabeça por sus delictos» ${ }^{50}$.

La práctica de remover y poner jueces adictos a una causa o de favorecer abiertamente a amigos, socios o parientes no sólo ponía de manifiesto la autoridad que gozaban ciertos grupos de poder en el concierto de la política local sino, fundamentalmente, la falta de elocuencia de algunos magistrados que actuaban más como «compadres» que como administradores. Este tipo de conducta constituía una práctica inaceptable para la administración de justicia,

\footnotetext{
48 Ibidem, fol.1221v.

49 Libro segundo de cartas del Tribunal de la Inquisición de Lima al Consejo de Inquisición y al Inquisidor General, 1575, AHN, Inquisición 1034, fol. 248.

50 Ibidem, fol. 272.
} 
en la medida en que los jueces debían actuar en nombre del monarca-legislador por antonomasia- desarrollando tareas de justicia y de gobierno. En ese sentido, debían infundirse de las mismas virtudes que emanaban de la persona del rey, entre ellas, la rectitud, la templanza, la modestia y la vigilancia ${ }^{51}$. Particularmente, se estimaba que el juez fuera recto en sus funciones a fin de poder proceder, incluso, contra amigos y parientes. Asimismo, se valoraba la templanza que le permitiría evitar cualquier afección hacia las partes y mantener una actitud equidistante respecto a los «administrados». No obstante, ambas cualidades parecerían estar ausentes en los magistrados que intervinieron en los procesos citados quienes favorecieron -con mayor o menor escándalo- a los sodomitas acusados.

\section{LA DESIGUALDAD COMO DERECHO}

Como puede observarse, la administración de la justicia colonial no siempre corrió por los carriles esperados. En el caso del tratamiento de la sodomía, esa tendencia pareció profundizarse, ya que al tratarse de un delito tan infamante -en el «que hasta la nobleza se pierde»- puso en movimiento una serie de estrategias tendientes a neutralizar o, por lo menos, minimizar los efectos de las sanciones judiciales que, en el extremo, suponía la muerte en la hoguera.

El éxito en esa tarea dependió del status así como de la influencia social y política de los individuos sindicados como sodomitas. De este modo, aquellos individuos pertenecientes a familias destacadas o integrantes de redes o grupos de poder tanto locales como de alcance virreinal, tuvieron la capacidad para influir sobre las decisiones de los magistrados cuando no violar los mecanismos y los procedimientos de la justicia, manipulando e, incluso, destruyendo las causas incoadas.

La apelación al privilegio que otorgaban los fueros fue otro de las estrategias que permitió a algunos sodomitas evitar el procesamiento o la aplicación de penas graves. Como se mencionara, las personas eclesiásticas hicieron uso de esta prerrogativa a fin de escapar del brazo secular, poniendo de manifiesto, además, las competencias y las rivalidades jurisdiccionales entre dos instancias encargadas de administrar justicia. Si bien la justicia foral contribuyó, en un sentido particular e inmediato, a preservar la integridad de sus miembros, también representó, en un sentido más amplio, un claro mecanismo para resguardar la honorabilidad de las instituciones y corporaciones que

51 Mantecon, 2002: 71-72. 
defendían. A diferencia de las presiones políticas que se ejercía «desde afuera» sobre el sistema judicial o del ejercicio corrupto de los magistrados, la apelación a los fueros para eludir a la justicia quedaba inscripta en los mecanismos formales y legales del sistema.

Como contracara, los sodomitas procedentes de los sectores subalternos de la sociedad colonial, ya sean peninsulares o criollos de baja laya así como negros, mulatos, mestizos e indios, tuvieron menos capacidad de negociación en el marco de la justicia. Esas limitaciones que procedían de su posición en la estructura social fueron reforzadas por los prejuicios y los estereotipos raciales y étnicos -tales como la inclinación de estos grupos hacia las conductas sexuales desordenadas- de los que se nutrieron los agentes encargados de administrar justicia y que fueron muy efectivos a la hora de juzgar y castigar a estos individuos.

En este escenario, cabe preguntarse, entonces, cuáles fueron los alcances y los límites de aquella disposición que aspiraba abarcar a «qualquier persona de qualquier estado, condición, preeminencia, o dignidad» que cometiera el crimen de sodomía. Si bien una primera respuesta pareciera sugerir un acentuado desfase entre la letra y la práctica judicial, lo cierto es que este tipo de concepción estaba ausente en la cultura jurídica colonial. Como señala Carlos Garriga, la justicia durante el período analizado, tenía una concepción del derecho que hoy consideraríamos «antilegalista», en la medida en que anteponía el derecho a la ley. A diferencia del orden jurídico legalista, representado como un jardín exquisitamente diseñado y cuidado por expertos jardineros -esto es, el jurista como legislador-, la justicia del Antiguo Régimen se presentaba como un espacio salvaje en el que el jurista actúa como un guardabosque a fin de mantener un orden dado que se vivía como natural y se concebía invariable ${ }^{52}$.

Por otra parte, en la medida en que en la sociedad colonial peruana ese «orden dado» se fundaba en la desigualdad tanto real como formal de los individuos -más allá de la fluidez y la movilidad social que mostró durante su temprana conformación- la pretendida universalidad con la que los códigos civiles buscaron sancionar a la sodomía resultaba inviable en una sociedad donde la desigualdad tenía su correlato en el plano judicial. A diferencia de las sociedades contemporáneas donde existe una contradicción entre las desigualdades reales y la noción de igualdad ante la ley, la sociedad colonial peruana hizo de la desigualdad un derecho que, al igual que la nobleza, no estaban dispuestos a perder.

52 Garriga, 2004: 15. 


\section{BiBLIOGRAFÍA}

Ares Queija, Berta, "Mestizos, mulatos y zambaigos (Virreinato del Perú, siglo XVI)", Berta Ares Queija y Alessandro Stella (coords.), Negros, mulatos, zambaigos: derroteros africanos en los mundos ibéricos, Madrid/Paris, CNRS/EEHS, 2000: 75-88.

Ares Queija, Berta, "Un borracho de chicha y vino: la construcción social del mestizo (Perú, siglo XVI)", Gregorio Salinero (coord.), Mezclado y sospechoso: movilidad e identidades, España y América (siglos XVI-XVIII), Madrid, Casa de Velázquez, 2000: 121-144.

Bataillon, Marcel, "Los colonos del Perú contra Carlos V. Análisis del movimientos Pizarrista (1544-1548)", Alberto Tauro (comp.), La Colonia, ensayos peruanistas, Lima, UNMSM, 1995 (1962): 79-96.

Bernand, Carmen, Negros esclavos y libres en las ciudades Hispanoamericanas, Madrid, Fundación Histórica Tavera, 2002.

Bonnett Vélez, Diana, "Las reformas de la época toledana (1569-1581): economía, sociedad, política, cultura y mentalidades", Manuel Burga (ed.), Historia de América Andina. Formación y apogeo del sistema colonial, Quito, Universidad Simón Bolívar, 1999: 99-131.

Borja Gómez, Jaime Humberto, "El control de la sexualidad: indios y negros (15501650)", Jaime Humberto Borja Gómez (comp.), Inquisición, muerte y sexualidad en Nueva Granada, Bogotá, Ceja-Ariel, 1996: 171-198.

Bowser, Frederick P., El esclavo africano en el Perú colonial (1524-1650), México, Siglo XXI, 1977 (1974).

Carlos IV, Rey, Novísima recopilación de leyes de España, Madrid, Imprenta de Sancha, 1805.

Elliot, John H, La España Imperial, 1469-1716, Barcelona, Vicens-Vives, 1998 (1987).

Elliot, John H, "España y América en los siglos XVI y XVII", Leslie Bethell (ed.), Historia de América Latina. 2. América Latina colonial. Europa y América en los siglos XVI, XVII, XVIII, Barcelona, Editorial Crítica, 1990: 3-44.

Garriga, Carlos, "Orden jurídico y poder político en el Antiguo Régimen”, Istor. Revista de Historia Institucional, IV/16 (México, 2004): 13-44.

Hespanha, Antonio Manuel, Cultura jurídica europea. Síntesis de un milenio, Madrid, Tecnos, 2002.

Levillier, Roberto (ed.), Gobernantes del Perú. Cartas y papeles siglo XVI. Documentos del Archivo de Indias. Tomo VI. El Virrey Francisco de Toledo, 1577-1580, Madrid, Imprenta de Juan Pueyo, 1924. 
Lohmannn Villena, G., Las ideas jurídico-políticas en la Rebelión de Gonzalo Pizarro: la tramoya doctrinal del levantamiento contra las Leyes Nuevas en el Perú, Valladolid, Casa Museo Colón, 1977.

Mantecon, Tomás A., "El mal uso de la justicia en la Castilla del siglo XVII", José I. Fortea et al., Furor et Rabies. Violencia, conflicto y marginación en la Edad Media, Santander, Servicio de Publicaciones de la Universidad de Cantabria, 2002: 69-98.

Molina, Fernanda, "El convento de Sodoma. Frailes, órdenes religiosas y sexualidad en el Virreinato del Perú (Siglos XVI-XVII)", HISTOIRE(s) de l'Amérique latine, 9 (París, 2013): 1-17.

Molina, Fernanda, "Entre pecado y delito. La administración de la justicia y los límites documentales para el estudio de la sodomía en el Virreinato del Perú (Siglos XVI-XVII)", Revista Allpanchis Phuturinqa, 71 (Cuzco, 2008): 141-186.

Molina, Fernanda, "Uniones en los márgenes: relaciones consensuales interétnicas en Charcas, siglo XVII", Colonial Latin American Historical Review, 15/1 (Alburquerque, 2006): 31-52.

Mörner, Magnus, La mezcla de las razas en la historia de América Latina, Buenos Aires, Paidos, 1969 (1967).

Murra, John V, "El doctor Barros de San Millán: Defensor de los 'señores naturales' de los Andes", John V. Murra, El mundo andino, población, medio ambiente y economía, Lima, IEP/PUCP, 2002: 426-438.

Olsen, Margaret M., "African Reinscription of Body and Space in New Granada", Santa Arias y Mariselle Meléndez (eds.), Mapping Colonial Spanish America: Places and Commonplaces of Identity, Culture, and Experience, Lewisburg, PA, Bucknell Univesity Press, 2002: 51-67.

Palomeque, Silvia., "El mundo indígena. Siglo XVI-XVIII", Enrique Tándeter (dir.), Nueva Historia Argentina. La sociedad colonial, vol. 2, Buenos Aires, Sudamericana, 2000: 87-143.

Poloni-Simard, Jacques, "Redes y mestizaje. Propuestas para el análisis de la sociedad colonial”, Guillaume Boccara y Sylvia Galindo (eds.), Lógica mestiza en América, Temuco, Instituto de Estudios Indígenas, Universidad de la Frontera, 2000: 114138.

Presta, Ana María, "Acerca de las primeras doñas mestizas de Charcas colonial, 1540-1590", Pilar Gonzalbo Aizpuru y Berta Ares Queija (eds.), Las mujeres en la construcción de las sociedades iberoamericanas, Sevilla, CSIC/COLMEX, 2004: 41-62.

Presta, Ana María, "La sociedad colonial: raza, etnicidad, clase y género. Siglos XVI y XVII", Enrique Tándeter (dir.), Nueva Historia Argentina. La sociedad colonial. Vol. 2, Buenos Aires, Sudamericana, 2000: 55-86. 
Schwartz, Stuart B. y Salomon, Frank, "New Peoples and New kinds of People: Adaptation, Readjustment, and Ethnogenesis in South American Indigenous Societies (Colonial Era)", Stuart B. Schwartz y Frank Salomon (eds.), The Cambridge History of the native People of the Americas, vol. 2, Cambridge, Cambridge University Press, 2000: 443-500.

Vallejo, Jesús y Petit, Carlos, "La categoria giuridica nella cultura europea del Medioevo", Gherardo Ortalli (ed.), Storia d'Europa. Il medioevo. Secoli V-XV, vol. 3, Torino, Einaudi, 1994: 721-760.

Fecha de recepción: 24 de mayo de 2012.

Fecha de aceptación: 5 de febrero de 2013.

\section{Between Double Standards and Privilege. The Administration of Justice Against Male Sodomy in the Viceroyalty of Peru $\left(16^{\text {th }}-17^{\text {th }}\right.$ Centuries)}

This paper investigates the both the civil and Episcopal legal actions taken on issues on issues related to the crime of sodomy in the Viceroyalty of Peru during the $16^{\text {th }}$ and $17^{\text {th }}$ centuries. The extent to which family, social and ethnic background, as well as the relationship of the accused with powerful networks or groups influenced the actions taken by the magistrates and the fulmination of the causes is a particular focus point of the study. Additionally, within the scope of these trials for sodomy, how the granting of privileges and corporate logic also served as possible effective mechanisms used to manipulate and avoid legal provisions is also examined.

KEY WORDS: sodomy; justice; privileges; Viceroyalty of Peru. 